\title{
White Mold Management in Common Bean by Increasing Within-Row Distance Between Plants
}

\author{
R. F. Vieira, T. J. Paula Júnior, and H. Teixeira, Empresa de Pesquisa Agropecuária de Minas Gerais, Vila Gianetti, \\ 47, Viçosa, MG 36570-000 Brazil; and J. E. de S. Carneiro, Departamento de Fitotecnia, Universidade Federal de \\ Viçosa, Viçosa, MG 36570-000 Brazil
}

\begin{abstract}
Vieira, R. F., Paula Júnior, T. J., Teixeira, H., and Carneiro, J. E. de S. 2010. White mold management in common bean by increasing within-row distance between plants. Plant Dis. 94:361367.

White mold of common bean (Phaseolus vulgaris), caused by Sclerotinia sclerotiorum, is a major yield-limiting disease during the fall-winter season in Brazil. This study was conducted to evaluate the efficacy of decreasing within-row densities for an indeterminate growth habit (type IIIa) cultivar, keeping constant the between-row spacing of $0.5 \mathrm{~m}$, to manage the disease. A modification of within-row plant distributions was also attempted in order to reduce white mold intensity. The study was conducted with sprinkler irrigation in two growing seasons (2000 and 2001) in Viçosa, State of Minas Gerais, Brazil, in an area naturally infested with sclerotia. In 2000 , treatments were arranged as $3 \times 2 \times 2$ factorial combination of within-row densities $(15$, 7.5 , or 5 plants $/ \mathrm{m}$ ), within-row plant distributions (single and equidistant plants or equidistant groups of three plants), and fluazinam treatments (with or without). In 2001, 16, 12, 8, or 4 plants $/ \mathrm{m}$ were combined with fluazinam treatments. Fluazinam was applied at both flowering onset and 10 or 13 days later. Average incidence was $92.6 \%$ in 2000 and $77.8 \%$ in 2001; severity index was $69.8 \%$ in 2000 and $40.2 \%$ in 2001; and yield was $1,656 \mathrm{~kg} / \mathrm{ha}$ in 2000 and 2,542 $\mathrm{kg} / \mathrm{ha}$ in 2001. White mold decreased and yield increased as within-row densities were reduced, regardless of fluazinam treatments. A distribution of equidistant groups of three plants was ineffective in reducing disease. The use of 4 equidistant plants $/ \mathrm{m}$ in infested irrigated areas was an effective strategy in white mold management.
\end{abstract}

Common beans (Phaseolus vulgaris L.) are cultivated in nearly every Brazilian state. However, most of the production is concentrated in eight states, which are responsible for approximately $80 \%$ of national production (7). Production is distributed in three distinctive seasons during the year (rainy, dry, and fall-winter). The rainy crop, harvested from November through February (sown from August through November), is concentrated in the states of the southern region. The dry crop is harvested from March through June in all regions, and the fall-winter crop is harvested from August through October in the tropical regions. The great variability in Brazilian common bean yields is a direct result of a corresponding variety of cropping technologies. The rainy crop uses a medium level of technology (includes correction of soil acidity, medium-level use of fertilizers and pesticides, generally high-yield cultivars, hand or mechanical harvesting). The dry crop uses low technology (little or no use of lime, fertilizer,

Corresponding author: R. F. Vieira

E-mail: rfvieira@epamig.br

Accepted for publication 25 November 2009.

doi:10.1094/PDIS-94-3-0361

(C) 2010 The American Phytopathological Society and pesticide, no irrigation, seeds obtained locally, hand harvesting), whereas the fallwinter crop uses high technology (correction of soil acidity, adequate fertilization, irrigation, pesticides, high-yield cultivars, mechanical or hand harvesting) and is concentrated in central and southeastern Brazil. The latter crop accounts for approximately $12 \%$ of beans produced in Brazil, and its average yield is over 2,000 $\mathrm{kg} / \mathrm{ha}$ (18).

The commercial common bean production system during the fall-winter season requires irrigation, and the indeterminate growth habit (type IIIa) cultivars used in this production system are prone to outbreaks of white mold caused by Sclerotinia sclerotiorum (Lib.) de Bary. "Carioca" grain class (cream-striped) is the most important bean class used in these regions. A few upright cultivars (type II) of "carioca" grain class are available for farmers, but because of their lower yield potential they are not well accepted. Common beans are generally sown at row spacing of 0.45 to $0.55 \mathrm{~m}$ with 10 to 12 plants $/ \mathrm{m}$ when medium or high technology is used. It is not unusual, however, to observe densities as high as 16 plants $/ \mathrm{m}$ in field plantings.

Management of white mold is difficult due to its temporal and spatial variability, and due to limited management options. The most commonly used control measure is the application of a fungicide during early bloom, and if conditions continue to be favorable for the disease additional applications are required (36). Fluazinam is the most effective fungicide used for white mold control in Brazil $(16,35,36)$. Agronomic practices such as wide row spacing and/or greater distance between plants within the row, by modifying microclimate, may reduce sclerotia germination $(9,14)$, apothecia production $(14,28)$, ascospore survival on plant tissue $(1,2,6)$, development of white mold on plants, and plant-to-plant transfer of mycelia $(5,10)$. According to $\mathrm{Tu}$ (32), narrow rows and high plant density reduce air circulation and trap moisture in the canopy. Therefore, the use of wider row spacing or within-row plant distance, or both, could help in the management of the disease. However, only a few studies can be found in the literature that cover row width and plant density for white mold control in common bean $(15,17,22,23,27,32)$. Some of these studies reported a reduction of either white mold intensity $(17,27,32)$ or sclerotia production per area (23) as row widths increased, but this strategy did not affect seed yield $(17,32)$.

According to Chad et al. (5), reduction of soybean plant population was more important than increasing row spacing to manage white mold in an irrigated area. In Canada, Saindon et al. (23) found no advantage of increasing within-row distance between plants for white mold management in irrigated common beans. However, the wider within-row distance between plants tested was 0.10 to $0.13 \mathrm{~m}$, equivalent to 7.7 to 10 plants $/ \mathrm{m}$.

Common bean potentially can be grown at low plant density without yield reduction. In Brazil, type IIIa cultivars, Pérola among them, sown at row widths of $0.5 \mathrm{~m}$, had no yield reduction when 5 to 20 plants/m were used in the absence of white mold (26). We hypothesized that increasing the distance between plants, therefore enhancing air circulation and light penetration into the canopy, would disfavor white mold development and would increase common bean yield.

The study was conducted to evaluate the efficacy of increasing the within-row distance between plants, keeping constant the between-row spacing of $0.5 \mathrm{~m}$, to manage white mold. A modification of within-row plant distribution was also attempted to reduce disease intensity. Considering that 
fungicide is used in irrigated fields for white mold control, common bean performance was tested with or without fungicide applications in irrigated fields.

\section{MATERIALS AND METHODS}

Research location, plot details, and cultivar. Field experiments were conducted in two consecutive growing seasons in 2000 and 2001 in Viçosa $\left(20^{\circ} 45^{\prime} 14^{\prime \prime} \mathrm{S}\right.$, $42^{\circ} 52^{\prime} 55^{\prime \prime} \mathrm{W}$, elevation $648 \mathrm{~m}$ ), State of Minas Gerais, Brazil. The area used is located at Federal University of Viçosa in a field naturally infested with sclerotia of $S$. sclerotiorum. Soil at the site is classified as Alfissol and has the following characteristics at a depth of 0 to $0.20 \mathrm{~m}: 53 \%$ clay, $24 \%$ silt, $23 \%$ sand, $\mathrm{P}=7.7 \mathrm{mg} / \mathrm{dm}^{3}, \mathrm{~K}=$ $175 \mathrm{mg} / \mathrm{dm}^{3}$ (Mehlich 1), $\mathrm{Ca}=4.5$ $\mathrm{cmol}_{\mathrm{c}} / \mathrm{dm}^{3}, \mathrm{Mg}=0.7 \mathrm{cmol}_{\mathrm{c}} / \mathrm{dm}^{3}(\mathrm{KCl}, 1$ $\mathrm{mol} /$ liter), and $\mathrm{pH}=5.8$. Soil $\mathrm{pH}$ was measured using a 1:2.5 soil-to-water ratio. Approximately 1 month before sowing, glyphosate (Roundup 480 SL; Helm do Brasil Mercantil) at 2 liters/ha was applied, and 2 days before sowing, the soil was disked to approximately $10 \mathrm{~cm}$ depth with a tandem disk. The area was irrigated with overhead sprinklers positioned $1.5 \mathrm{~m}$ above ground level. Irrigation was provided as needed to promote good seedling emergence and at a rate of approximately $5.0 \mathrm{~cm}$ of water per week thereafter as generally used in the region.

Five weather variables (precipitation, maximum and minimum temperature, sunshine duration, and relative humidity) were recorded hourly during the growing season at an automatic weather station located about $300 \mathrm{~m}$ from the experiments. Data were reported as monthly means (Table 1).

Each plot was four rows $0.5 \mathrm{~m}$ apart and $5 \mathrm{~m}$ long. The space between plots and blocks was $1 \mathrm{~m}$. At planting, a commercial fertilizer (4 N: 6.1 P: $6.6 \mathrm{~K}$ ) was applied in bands along with the seeds at $700 \mathrm{~kg} / \mathrm{ha}$. Plants were harvested when at least $90 \%$ of the pods were brownish tan. All plants from the two center rows (discarding $0.5 \mathrm{~m}$ at both ends of the plot) were used for white mold evaluation and yield determination. The common bean cultivar Pérola is widely used in Brazil. It has an indeterminate growth habit (type IIIa) and a "carioca" grain class (cream-striped). Seed germination was $90 \%$.
2000 field experiment. Seed was sown on 2 May 2000. Treatments were arranged as $3 \times 2 \times 2$ factorial combination of within-row densities of $15,7.5$, or 5 plants/m, within-row plant distributions (single and equidistant plants or equidistant groups of three plants), and fungicide treatments (with or without). The withinrow densities were obtained by seeding the rows with $50 \%$ more seeds than planned plant densities and subsequent thinning at V3 developmental stage to nearly uniform distances between either plants or groups of three plants. In the latter planting pattern, each group of three plants was spaced in the row by $0.2,0.4$, or $0.6 \mathrm{~m}$ to achieve the within-row densities of $15,7.5$, and 5 plants $/ \mathrm{m}$, respectively. The distance among plants within groups of three was between 2 and $5 \mathrm{~cm}$. The cultural practice of planting by digging holes with a hoe and putting three seeds in each hole is widely used by low-income farmers in Brazil. The statistical design was a randomized complete block with six replicates. The fungicide fluazinam (Frowncide $500 \mathrm{SC}$; Ishihara Brasil Defensivos Agrícolas) was applied at $0.5 \mathrm{~kg} / \mathrm{ha}$ for white mold control at both 49 days after emergence (DAE; $30 \%$ of plants with at least one open flower, R6 stage) and 62 DAE (all plants simultaneously had flowers and small pods, R7 stage). The manufacturer's instructions for white mold control in common bean are one application of fluazinam at flower onset followed by one or two applications at 7- to 10-day intervals. In this experiment, the second fluazinam application was delayed beyond the tenth day because no diseased plant was observed until the thirteenth day when application was made. A backpack sprayer equipped with two hollow cone nozzles spaced $0.5 \mathrm{~m}$ apart that delivered 667 liters/ha at $207 \mathrm{kPa}$ was used. At R6 and R7 stages, besides the application of fluazinam, plants were preventively sprayed with the fungicide azoxystrobin (Amistar 500 WG; Syngenta Proteção de Cultivos, Brazil) at $0.08 \mathrm{~kg} / \mathrm{ha}$ in order to control angular leaf spot caused by Pseudocercospora griseola (Sacc.) Crous \& U. Braun and anthracnose caused by Colletotrichum lindemuthianum (Sacc. \& Magn.) Scrib.

Urea $(150 \mathrm{~kg} / \mathrm{ha})$ was applied as a side dressing at 23 DAE (V4 stage). At this time, plants were also sprayed with a solu- tion of sodium molybdate $(0.04 \mathrm{~kg} / \mathrm{ha}$ of Mo). For purple nutsedge (Cyperus rotun$d u s$ L.) control on the plots and for control of other weeds located between rows, a manual hoe-weeding was made at 26 DAE. Two days later, a commercial mixture of the herbicides fomesafen at $0.25 \mathrm{~kg} / \mathrm{ha}$ and fluazifop-p-butil at $0.20 \mathrm{~kg} / \mathrm{ha}$ (Robust microemulsion; Syngenta Proteção de Cultivos, Brazil) was applied to control weeds within rows. Control of pests, especially leafhopper (Empoasca kraemeri Ross \& Moore, 1957), was made with the insecticide deltamethrin (Decis $50 \mathrm{SC}$; Bayer - Proteção de Plantas, Brazil) at $0.08 \mathrm{~kg} / \mathrm{ha}$ or metamidophos (Tamaron 600 SL; Proteção de Plantas, Brazil) at 0.4 $\mathrm{kg} / \mathrm{ha}$. Deltamethrin was applied at V4 stage and metamidophos at both the R6 and R7 stages.

2001 field experiment. Seed was sown on 24 April 2001. Treatments were arranged as $4 \times 2$ factorial combination of within-row densities $(16,12,8$, or 4 plants $/ \mathrm{m}$ ) and fungicide treatments (with or without). Sowing was done with $50 \%$ $(16,12$, and 8 plants $/ m)$ or $75 \%$ (4 plants $/ \mathrm{m}$ ) more seeds than necessary for the planned plant population. Thinning was done at V3 and V4 stages to achieve the desired population. At V4 stage, azoxystrobin was applied in order to reduce the foliar disease mentioned in the previous experiment. The statistical design was a randomized complete block with six replicates. The fungicide fluazinam was applied at both 45 DAE (40\% of plants with at least one open flower, R6 stage) and 55 DAE (R7 stage) as described previously.

Seeds were treated with imidacloprid insecticide (Gaucho 700 WS; Proteção de Plantas, Brazil) at $1.4 \mathrm{~g} / \mathrm{kg}$ before sowing. The herbicide metolachlor (Dual Gold 960 EC; Syngenta Proteção de Cultivos, Brazil) was applied at $1.2 \mathrm{~kg} / \mathrm{ha}$ on the soil at the sowing day. A commercial mixture of the herbicides fomesafen and fluazifop- $p$ butil was applied at the V3 stage over the bean plants and weeds. Urea $(100 \mathrm{~kg} / \mathrm{ha})$ was applied as a side dressing at the V4 stage. At this time, plants were also sprayed with a solution of sodium molybdate $(0.04 \mathrm{~kg} / \mathrm{ha}$ of Mo). Metamidophos was applied four times between the V3 and V8 stages for leafhopper control.

Data collection and statistical analysis. Data were obtained for canopy closure,

Table 1. Average monthly weather conditions during two growing season at Viçosa, State of Minas Gerais, Brazil

\begin{tabular}{|c|c|c|c|c|c|c|c|c|c|c|}
\hline \multirow[b]{2}{*}{ Month } & \multicolumn{2}{|c|}{ Precipitation (mm) } & \multicolumn{2}{|c|}{ Temp., max. $\left({ }^{\circ} \mathrm{C}\right)$} & \multicolumn{2}{|c|}{ Temp., min. $\left({ }^{\circ} \mathrm{C}\right)$} & \multicolumn{2}{|c|}{ Sunshine duration (h) } & \multicolumn{2}{|c|}{ Rel. humidity (\%) } \\
\hline & 2000 & 2001 & 2000 & 2001 & 2000 & 2001 & 2000 & 2001 & 2000 & 2001 \\
\hline May $^{\mathrm{a}}$ & 6.0 & 59.5 & 25.2 & 26.3 & 13.0 & 14.7 & 201 & 210 & 84 & 79 \\
\hline June $^{\mathrm{b}}$ & 14.4 & 0.2 & 24.8 & 25.6 & 10.6 & 13.3 & 235 & 209 & 87 & 81 \\
\hline July & 13.6 & 2.0 & 22.8 & 25.0 & 11.4 & 11.7 & 168 & 205 & 87 & 78 \\
\hline August $^{c}$ & 19.1 & 6.4 & 25.6 & 26.5 & 11.7 & 12.4 & 204 & 244 & 85 & 75 \\
\hline
\end{tabular}

a Emergence date: 10 May 2000 and 4 May 2001.

${ }^{\mathrm{b}}$ Flowering date: 28 June 2000 (30\% of plants with at least one open flower) and 18 June 2001 (40\% of plants with at least one open flower).

c Harvest date: 27 to 30 August 2000 and 15 to 20 August 2001. 
white mold incidence and severity, seed yield, and seed yield components. Canopy closure was evaluated visually at the time of fluazinam applications in 2000 and at 45 (R6 stage) and 79 DAE (R8 stage) in 2001 by observing each plot from one end (looking down the rows) and visually estimating the proportion of soil surface visible between the rows (100\% representing complete ground cover) (12). Dates of emergence (when rows of plants were visible), flowering (30 or $40 \%$ of plants with at least one open flower), and harvest each year are provided in footnotes in Table 1. Plants in each plot were rated for disease severity index (DSI) and disease incidence (13) by means of a "quarter scale" (8). Plants were rated from 0 to 4 , where $0=$ no symptoms, $1=$ 1 to $25 \%$ of the plant with symptoms, $2=$ 26 to $50 \%$ of the plant with symptoms, 3 $=51$ to $75 \%$ of the plant with symptoms, and $4=76$ to $100 \%$ of the plant with symptoms. DSI was calculated for each plot on a percentage basis by the following formula:

$\operatorname{DSI}(\%)=\frac{\sum(\text { scores of all plants })}{4 \times(\text { total number of plants })} \times 100$

In the 2001 experiment, sclerotia larger than $3 \mathrm{~mm}$ were separated from seeds of each plot and weighed. Five yield components were considered: final plant population, pods per plant, pods per square meter, seeds per pod, and 100-seed weight. The number of pods per plant, pods per square meter, and seeds per pod were obtained from all plants harvested. Seed yield was determined after harvested seed had been dried to a constant weight. Yield was adjusted to $120 \mathrm{~g} / \mathrm{kg}$ moisture.

Data were analyzed for homogeneity of variance with Bartlett's test and for normality with Lilliefors's test using the software program "Sistema para Análises Estatísticas" (SAEG) (21). Percent canopy closure, white mold incidence, and weight of sclerotia did not meet the homogeneity of variance and/or normality assumption. Thus, they were transformed using either arcsine square root or square root before analysis. Significant $F$ ratio was used to determine significant differences between mean values. Regression procedures were used to test linear, quadratic, and in the case of the 2001 experiment, cubic functions for common bean variables versus within-row densities, based on results of the factorial analysis. These analysis procedures were performed using the software program SAEG (21).

\section{RESULTS}

Weather effects. Weather conditions were more favorable for white mold development in 2000 than in 2001 (Table 1), especially after flowering onset: more precipitation, lower temperatures, cloudier days, and higher relative humidity. In 2000, common bean plants required 109 to 112 days from emergence to reach maturity; in 2001, 103 to 108 days. During the middle reproductive phase in July of 2000, weather conditions were particularly favorable for white mold. The combination of cloudy days with 8 days of light rain (data not shown) associated with low temperatures and high relative humidity favored disease development. Thus in 2000, average incidence was $92.6 \%$, DSI was $69.8 \%$, and yield was $1,656 \mathrm{~kg} / \mathrm{ha}$; whereas in 2001 , they were $77.8 \%, 40.2 \%$, and $2,542 \mathrm{~kg} / \mathrm{ha}$, respectively.

2000 field experiment. The interaction within-row densities $\times$ within-row plant distributions was not significant for incidence, but was significant for DSI (Table 2 ). Incidence decreased linearly with decreasing within-row densities from 15 to 5 plants/m (Tables 2 and 3). Interactions involving fungicide treatments were not significant for any variable (Table 2). Fluazinam decreased DSI and disease incidence (Tables 2 and 3) relative to the unsprayed treatment. Compared with the unsprayed treatment, fluazinam applications decreased disease incidence from 98.9 to 84.6 (Table 3), whereas the reduction of 11 plants/m (current average plant density recommended) to 5 plants $/ \mathrm{m}$ de- creased disease incidence from 80.0 to 75.4 according to the following regression: $y=71.62+0.764 x, r^{2}=0.84$, where $y$ is the arcsine square root of incidence and $x$ is within-row density. Within-row plant distributions had no effect on disease (Table 2).

Canopy closure at 49 and 62 DAE decreased linearly $(P<0.001)$ with the reduction of within-row densities for both within-row plant distributions (Fig. 1). At 49 DAE, canopy closure with 15 plants $/ \mathrm{m}$ in equidistant groups of three was greater than with single and equidistant plants $(P$ $<0.001)$; the opposite happened with 5 plants/m $(P<0.001)$ (Fig. 1A). At 62 DAE, again 5 plants $/ \mathrm{m}$ in equidistant groups of three covered less ground than did single and equidistant plants $(P<$ 0.001 ), but the difference between withinrow plant distributions with 15 plants $/ \mathrm{m}$ disappeared (Fig. 1B). With 7.5 plants $/ \mathrm{m}$, there was no difference between withinrow plant distributions at 49 DAE (Fig. $1 \mathrm{~A})$, but there was greater canopy closure with single and equidistant plants than with equidistant groups of three plants at 62 DAE $(P<0.05)$ (Fig. 1B).

The within-row densities of $15,7.5$, and 5 plants $/ \mathrm{m}$ corresponded to a final plant population per hectare of $284,000(5.3 \%$ less than the planned plant population at the V3 stage), 151,200 (0.8\% more), and 104,600 (4.6\% more) (Table 3). Number of pods per plant increased linearly as withinrow densities decreased, but within-row densities had no effect on number of pods $/ \mathrm{m}^{2}$ (Tables 2 and 3 ). Thus, increase of seed yield with decreasing within-row densities was directly related to more seeds per pod and heavier seeds (Tables 2 and 3). Except for 100-seed weight, within-row plant distributions had no effect on yield components (pods/plant, pods $/ \mathrm{m}^{2}$, and seeds/pod); however, the increase in seed weight was not high enough to increase yield (Tables 2 and 3). Compared to treatments that were not sprayed, fluazinam increased all yield components (Tables 2 and 3). Fluazinam applications increased

Table 2. Statistical probabilities of $F$ tests for main effects of within-row density and fungicide application and their interactions on white mold development, canopy closure, and yield and yield components of common bean in 2000 at Viçosa, State of Minas Gerais, Brazil

\begin{tabular}{|c|c|c|c|c|c|c|c|c|c|c|}
\hline Source of variation & df & DSI $^{\mathbf{a}}$ & Incidence & $\mathrm{CC}_{4} 9^{\mathrm{b}}$ & $\mathrm{CC}^{2} 2^{\mathrm{b}}$ & Yield & $\begin{array}{l}\text { Pods/ } \\
\text { plant }\end{array}$ & $\begin{array}{l}\text { Pods/ } \\
\text { m }^{2}\end{array}$ & $\begin{array}{l}\text { Seeds/ } \\
\text { pod }\end{array}$ & $\begin{array}{c}\text { 100-seed } \\
\text { weight }\end{array}$ \\
\hline Within-row densities (WRD) & 2 & $* * *$ & ** & $* * *$ & **** & $* * *$ & $* * *$ & $\mathrm{NS}^{\mathrm{c}}$ & **** & ** \\
\hline Linear & 1 & $* * *$ & $* * *$ & $* * *$ & $* * *$ & $* * *$ & $* * *$ & NS & $* * *$ & $* * *$ \\
\hline Quadratic & 1 & NS & NS & NS & NS & NS & NS & NS & * & NS \\
\hline $\begin{array}{l}\text { Within-row plant } \\
\text { distributions (WRPD) }\end{array}$ & 1 & NS & NS & NS & $* *$ & NS & NS & NS & NS & ** \\
\hline WRD × WRPD & 2 & $*$ & NS & $* * *$ & ** & NS & NS & NS & NS & NS \\
\hline Fluazinam treatments (FT) & 1 & $* * *$ & $* * *$ & * & NS & **** & $* * *$ & $* * *$ & $* * *$ & $* * *$ \\
\hline $\mathrm{WRD} \times \mathrm{FT}$ & 2 & NS & NS & NS & NS & NS & NS & NS & NS & NS \\
\hline $\mathrm{WRPD} \times \mathrm{FT}$ & 1 & NS & NS & NS & NS & NS & NS & NS & NS & NS \\
\hline $\mathrm{WRD} \times \mathrm{WRPD} \times \mathrm{FT}$ & 2 & NS & NS & NS & NS & NS & NS & NS & NS & NS \\
\hline
\end{tabular}

${ }^{a}$ Significance level: $* P \leq 0.05$, ** $P \leq 0.01$, *** $P \leq 0.001$. DSI $=$ disease severity index. Plants were rated from 0 to 4 , where $0=$ no symptoms, $1=1$ to $25 \%$ of the plant with symptoms, $2=26$ to $50 \%, 3=51$ to $75 \%$, and $4=76$ to $100 \%$. DSI was calculated for each plot on a percentage basis by the following formula: $\operatorname{DSI}(\%)=\Sigma$ (scores of all plants) $/[4 \times($ total number of plants $)] \times 100$.

${ }^{\mathrm{b}}$ CC49 = canopy closure at 49 days after emergence (DAE), R6 developmental stage. CC62 = canopy closure at 62 DAE, R7 stage.

c NS: not significant at the $P=0.05$ level. 
yield by $1,233 \mathrm{~kg} / \mathrm{ha}$ compared to unsprayed treatment (Table 3), whereas 5 plants $/ \mathrm{m}$ increased yield by $276 \mathrm{~kg} / \mathrm{ha}$ relative to 11 plants $/ \mathrm{m}$ according to the following regression: $y=2077.6-45.97 x$, $r^{2}=0.96$.

2001 field experiment. Within-row densities $\times$ fungicide treatment interactions were not significant for any variable (Table 4). DSI, incidence, and sclerotia weight decreased linearly $(P<0.01)$ with reduction of within-row densities from 16 to 4 plants/m (Tables 4 and 5). Fluazinam applications reduced DSI relative to unsprayed treatments $(P<0.05)$, but had no effect on either incidence or sclerotia weight. Compared to unsprayed treatment, fluazinam applications decreased DSI from 45.7 to $34.5 \%$ (Table 5), whereas reduction from 11 to 5 plants/m decreased DSI from 42.1 to $30.7 \%\left(y=21.26+1.893 x, r^{2}=\right.$ $0.98)$.
Canopy closure at 45 and 79 DAE decreased linearly $(P<0.001)$ with the reduction of within-row densities (Tables 4 and 5). Fluazinam increased canopy closure compared to unsprayed treatments only at $79 \operatorname{DAE}(P<0.01$, Tables 4 and 5$)$.

The within-row densities of $16,12,8$, and 4 plants $/ \mathrm{m}$ corresponded to a final plant population per hectare of 294,200 ( $8.1 \%$ less than the planned plant population at the V4 stage), 222,500 (7.3\% less), $156,100(2.4 \%$ less $)$, and $79,700(0.4 \%$ less) (Table 6). Number of pods per plant increased linearly and pods $/ \mathrm{m}^{2}$ decreased linearly as within-row densities decreased (Tables 4 and 6). Reductions of pod production per area with decreasing of withinrow densities were compensated by increasing seed production per pod and seed weight (Tables 4 and 6). As a consequence, seed yield increased as within-row densities diminished (Table 6). Compared to unsprayed treatments, two fluazinam applications increased all yield components (Tables 4 and 6), especially pods per plant and 100-seed weight. Fluazinam applications increased yield by $662 \mathrm{~kg} / \mathrm{ha}$ compared to the unsprayed treatment, whereas 4 plants $/ \mathrm{m}$ increased yield $(y=2731.1$ $18.89 x, r^{2}=0.87$ ) by $133 \mathrm{~kg} / \mathrm{ha}$ compared to 11 plants $/ \mathrm{m}$.

\section{DISCUSSION}

White mold intensity was reduced and seed yield was increased as within-row densities decreased from 15 to 5 plants $/ \mathrm{m}$ (2000 experiment) and from 16 to 4 plants/m (2001 experiment), at a constant between-row spacing of $0.5 \mathrm{~m}$, using an indeterminate growth habit (type IIIa) common bean. In 2000, when disease intensity was severe, a combination of cloudy days with 8 days of light rain associated with low temperature and high rela-

Table 3. Effects of within-row density, within-row plant distribution, and fluazinam treatment on white mold intensity, and yield and yield components of common bean in 2000 at Viçosa, State of Minas Gerais, Brazil

\begin{tabular}{|c|c|c|c|c|c|c|c|c|}
\hline Treatment & $\begin{array}{l}\text { Final plant population } \\
(\text { no./ha } \times 1,000)^{\mathrm{a}}\end{array}$ & $\begin{array}{l}\text { DSI } \\
(\%)^{\mathbf{b}}\end{array}$ & $\begin{array}{l}\text { Incidence } \\
\qquad(\%)^{\mathrm{c}}\end{array}$ & $\begin{array}{l}\text { Yield } \\
\text { (kg/ha) }\end{array}$ & Pods/plant & Pods $/ \mathbf{m}^{2}$ & Seeds/pod & $\begin{array}{c}\text { 100-seed } \\
\text { weight }(\mathrm{g})\end{array}$ \\
\hline \multicolumn{9}{|l|}{ Within-row densities ${ }^{d}$} \\
\hline 15 & $284.0 \pm 16.5$ & 78.9 & 96.7 & 1,394 & 7.0 & 225.7 & 3.82 & 19.0 \\
\hline 7.5 & $151.2 \pm 11.9$ & 70.5 & 95.3 & 1,710 & 14.8 & 224.8 & 4.32 & 19.8 \\
\hline 5 & $104.6 \pm 9.15$ & 60.0 & 83.2 & 1,865 & 22.3 & 214.4 & 4.51 & 20.3 \\
\hline \multicolumn{9}{|c|}{ Within-row plant distributions $\mathrm{e}^{\mathrm{e}}$} \\
\hline Equidistant plants & $183.4 \pm 77.2$ & 69.7 & 92.9 & 1,644 & 14.5 & 229.5 & 4.21 & 19.3 \\
\hline Equidistant groups & $176.6 \pm 79.4$ & 69.9 & 90.6 & 1,668 & 14.9 & 213.9 & 4.22 & 20.2 \\
\hline \multicolumn{9}{|l|}{ Fungicide treatments ${ }^{\mathrm{f}}$} \\
\hline Without & $180.0 \pm 81.1$ & 83.8 & 98.9 & 1,040 & 11.4 & 169.2 & 3.93 & 18.2 \\
\hline With & $180.0 \pm 77.5$ & 55.8 & 84.6 & 2,273 & 18.0 & 274.1 & 4.51 & 21.2 \\
\hline
\end{tabular}

${ }^{\mathrm{a}}$ Mean \pm SD.

${ }^{\mathrm{b}} \mathrm{DSI}=$ disease severity index.

${ }^{\mathrm{c}}$ Data were transformed using arcsine square root before analysis, but untransformed means are presented.

${ }^{\mathrm{d}}$ Data are pooled across within-row plant distributions and fungicide treatments. The planned plant populations at V3 developmental stage were 15, 7.5, and 5 plants $/ \mathrm{m}$, corresponding to 300,150 , and 100 thousand plants/ha, respectively.

${ }^{\mathrm{e}}$ Data are pooled across within-row densities and fungicide treatments. Equidistant plants $=$ single and equidistant plants, equidistant groups $=$ equidistant groups of three plants.

${ }^{\mathrm{f}}$ Data are pooled across within-row densities and within-row plant distributions. Fluazinam was applied at 49 (R6 developmental stage) and 62 days after emergence (R7 stage) at $0.5 \mathrm{~kg}$ a.i./ha in a volume of water equivalent to 667 liters/ha.
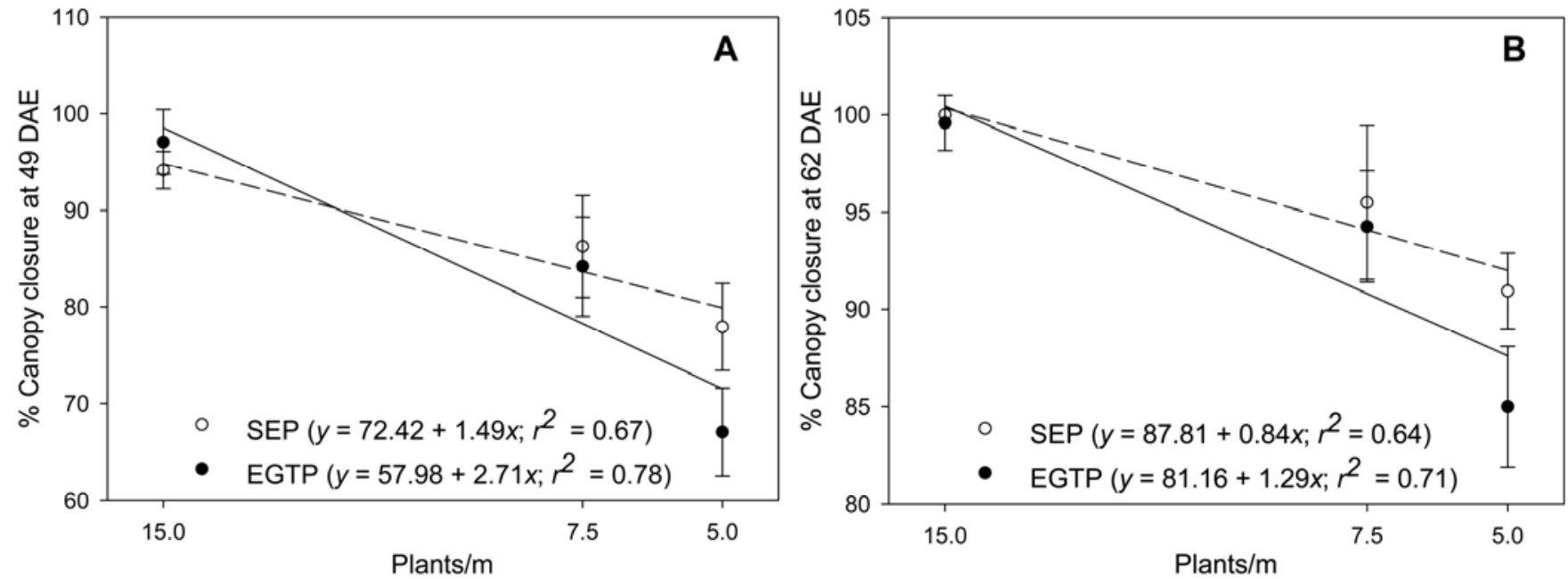

Fig. 1. Regression relationship between within-row density and common bean canopy closure at A, 49 and $\mathbf{B}, 62$ days after emergence (DAE) using single and equidistant plants (SEP) or equidistant groups of three plants (EGTP) within-row at Viçosa, State of Minas Gerais, Brazil. Data were transformed using arcsine square root (49 DAE) or square root (62 DAE) before analysis, but untransformed means are presented. Each point represents the mean of 12 replicates (data were pooled across fungicide treatments). Error bar represents standard deviation. 
tive humidity favored disease development during the middle reproductive phase of common bean. Soil temperature, soil moisture, and light govern sclerotial germination and development of apothecia $(1,19)$. Ascospores require wetness for germination and infection (1). Results also showed that 4 or 5 plants $/ \mathrm{m}$, compared to the current recommendation of 11 plants $/ \mathrm{m}$, was either less effective than fungicide when disease pressure was high (2000) or more effective than fungicide when disease pressure was medium (2001). However, in both situations, fluazinam applications, relative to unsprayed treatment, provided a yield increase $(1,233 \mathrm{~kg} / \mathrm{ha}$ in 2000 and 662 $\mathrm{kg} / \mathrm{ha}$ in 2001) greater than that achieved with low plant density compared to 11 plants/m (276 kg/ha in 2000 and $133 \mathrm{~kg} / \mathrm{ha}$ in 2001). The better control of anthracnose and angular leaf spot provided by fluazinam plus azoxystrobin, relative to azoxystrobin alone (data not shown), explains part of these results. Furthermore, plants that received fluazinam developed more foliage than unsprayed plants, as can be seen by the significant $F$ tests for fluazinam treatments on canopy closure at 49 DAE in 2000 (Table 2) and on canopy closure at 79 DAE in 2001 (Table 4). The lack of an interaction between within-row plant densities and fungicide treatments in both years suggests that the effects of a less dense stand and fluazinam applications are additive. These findings may not be applicable to determinate growth habit (type I) or indeterminate growth habit (type II) common bean cultivars since such plants do not exhibit phenotypic plasticity as do type III plants to compensate low plant density.

In Brazil, in the absence of white mold and with the same cultivar and row width used in this study, there was no yield reduction when within-row densities were reduced from 10 plants $/ \mathrm{m} \quad(200,000$ plants/ha) to 5 plants/m (26) or 4 plants $/ \mathrm{m}$ (20). Teixeira et al. (29) tested four sowing densities $(6,10,14$, and 18 seeds $/ \mathrm{m})$ and four rates of nitrogen $(0,50,100$, and 150 $\mathrm{kg} / \mathrm{ha}$ ) using the cultivar Pérola planted in rows $0.5 \mathrm{~m}$ apart. They found that it was only when $\mathrm{N}$ was not applied that common bean yield increased with increasing sow- ing densities. In Brazil, white mold is usually a constraint during the fall-winter season when type IIIa common bean cultivars are well fertilized and sprinkler irrigated. We speculate that, in the absence of the disease, little variation in yield is expected when within-row densities vary from 4 to 12 plants/m in this season. With an intermediate or high disease pressure level, our study showed that low withinrow densities can result in higher yield compared to the recommended within-row plant densities of 10 to 12 plants $/ \mathrm{m}$.

Reduction of within-row densities decreased both canopy closure (Tables 2 and 4) and plant mortality rates (Tables 3 and 6). More air movement within the canopy and less soil and plant surface moisture are probably the main reasons for reduced disease in wider within-row plant spacing. Carpogenic germination of sclerotia requires prolonged periods of wet soil and

Table 5. Effects of within-row density and fungicide treatment on white mold intensity and canopy closure of common bean in 2001 at Viçosa, State of Minas Gerais, Brazil

\begin{tabular}{|c|c|c|c|c|c|}
\hline Treatment & $\operatorname{DSI}(\%)^{\mathrm{a}}$ & WMI $(\%)^{b}$ & $\begin{array}{c}\text { Sclerotia } \\
\text { weight }(g)^{\mathrm{c}}\end{array}$ & $\operatorname{CC45}(\%)^{\mathrm{d}}$ & $\operatorname{CC79}(\%)^{\mathrm{d}}$ \\
\hline \multicolumn{6}{|c|}{ Within-row densities ${ }^{\mathrm{e}}$} \\
\hline 16 & 50.5 & 88.7 & 0.79 & 93.7 & 89.2 \\
\hline 12 & 44.6 & 84.2 & 0.81 & 89.2 & 87.5 \\
\hline 8 & 38.3 & 79.4 & 0.50 & 83.7 & 87.1 \\
\hline 4 & 27.4 & 59.0 & 0.26 & 67.9 & 82.9 \\
\hline \multicolumn{6}{|c|}{ Fungicide treatments ${ }^{f}$} \\
\hline Without & 45.7 & 79.5 & 0.76 & 83.5 & 85.2 \\
\hline With & 34.5 & 76.2 & 0.42 & 83.7 & 88.1 \\
\hline
\end{tabular}

${ }^{\text {a }}$ DSI = disease severity index.

${ }^{\mathrm{b}} \mathrm{WMI}=$ white mold incidence.

${ }^{c}$ Larger than $3 \mathrm{~mm}$ and mixed with seeds harvested in $3 \mathrm{~m}^{2}$. Data were transformed using square root plus 0.5 before analysis, but untransformed means are presented.

${ }^{\mathrm{d}}$ CC45 = canopy closure at 45 days after emergence (DAE), R6 developmental stage. Data were transformed using arcsine square root before analysis, but untransformed means are presented. CC79= canopy closure at 79 DAE, R8 stage. Data were transformed using square root before analysis, but untransformed means are presented.

e Data are pooled across fungicide treatments.

${ }^{\mathrm{f}}$ Data are pooled across within-row densities. Fluazinam was applied at 45 (R6 stage) and 55 DAE (R7 stage) at $0.5 \mathrm{~kg}$ a.i./ha in a volume of water equivalent to 667 liters $/ \mathrm{ha}$.

Table 6. Effects of within-row density and fluazinam treatment on seed yield and yield components in 2001 at Viçosa, State of Minas Gerais, Brazil

\begin{tabular}{|c|c|c|c|c|c|c|}
\hline Treatments & $\begin{array}{l}\text { Final plant population } \\
(\text { no./ha } \times 1,000)^{\mathrm{a}}\end{array}$ & $\begin{array}{l}\text { Yield } \\
\text { (kg/ha) }\end{array}$ & $\begin{array}{l}\text { Pods/ } \\
\text { plant }\end{array}$ & $\begin{array}{c}\text { Pods/ } \\
\mathbf{m}^{2}\end{array}$ & $\begin{array}{l}\text { Seeds/ } \\
\text { pod }\end{array}$ & $\begin{array}{r}\text { 100-seed } \\
\text { weight }(g)\end{array}$ \\
\hline \multicolumn{7}{|c|}{ Within-row densities ${ }^{b}$} \\
\hline 16 & $294.2 \pm 24.1$ & 2,396 & 10.3 & 256 & 4.20 & 22.3 \\
\hline 12 & $222.5 \pm 14.1$ & 2,538 & 11.4 & 267 & 4.33 & 23.4 \\
\hline 8 & $156.1 \pm 11.4$ & 2,612 & 17.7 & 238 & 4.48 & 23.8 \\
\hline 4 & $79.7 \pm 2.6$ & 2,623 & 26.7 & 223 & 4.64 & 25.0 \\
\hline \multicolumn{7}{|c|}{ Fungicide treatments ${ }^{\mathrm{c}}$} \\
\hline Without & $186.9 \pm 84.4$ & 2,211 & 15.1 & 232 & 4.33 & 23.0 \\
\hline With & $189.3 \pm 80.4$ & 2,873 & 17.9 & 260 & 4.50 & 24.3 \\
\hline
\end{tabular}

a Mean \pm SD.

${ }^{\mathrm{b}}$ Data are pooled across fungicide treatments. The planned plant populations at the V4 developmental stage were $16,12,8$, and 4 plants/m, corresponding to $320,240,160$, and 80 thousand plants/ha, respectively.

${ }^{c}$ Data are pooled across within-row densities. Fluazinam was applied at 45 (R6 stage) and 55 days after emergence (R7 stage) at $0.5 \mathrm{~kg}$ a.i./ha in a volume of water equivalent to 667 liters/ha.

Table 4. Statistical probabilities of $F$ tests for main effects of within-row density and fungicide application and their interactions on white mold development, canopy closure, and yield and yield components of common bean in 2001 at Viçosa, State of Minas Gerais, Brazil

\begin{tabular}{|c|c|c|c|c|c|c|c|c|c|c|c|}
\hline Source of variation & df & DSI $^{\mathbf{a}}$ & Incidence & $\begin{array}{c}\text { Sclerotia } \\
\text { weight }\end{array}$ & $\mathrm{CC} 5^{\mathrm{b}}$ & $\mathrm{CC} \mathrm{9}^{\mathrm{b}}$ & Yield & $\begin{array}{l}\text { Pods/ } \\
\text { plant }\end{array}$ & $\begin{array}{l}\text { Pods/ } \\
\mathbf{m}^{2}\end{array}$ & $\begin{array}{l}\text { Seeds/ } \\
\text { pod }\end{array}$ & $\begin{array}{c}\text { 100-seed } \\
\text { weight }\end{array}$ \\
\hline $\begin{array}{l}\text { Within-row densities } \\
\text { (WRD) }\end{array}$ & 3 & $*$ & $*$ & $*$ & $* * *$ & $* * *$ & $\mathrm{NS}^{\mathrm{c}}$ & $* * *$ & $*$ & $* * *$ & $* * *$ \\
\hline Linear & 1 & ** & ** & ** & $* * *$ & $* * *$ & * & $* * *$ & ** & $* * *$ & $* * *$ \\
\hline Quadratic & 1 & NS & NS & NS & ** & NS & NS & $* * *$ & NS & NS & NS \\
\hline Cubic & 1 & NS & NS & NS & NS & NS & NS & NS & NS & NS & NS \\
\hline Fluazinam treatments (FT) & 1 & * & NS & NS & NS & ** & $* * *$ & $* * *$ & $* *$ & $* *$ & $* * *$ \\
\hline $\mathrm{WRD} \times \mathrm{FT}$ & 3 & NS & NS & NS & NS & NS & NS & NS & NS & NS & NS \\
\hline
\end{tabular}

a Significance level: $* P \leq 0.05$, ** $P \leq 0.01$, ***P $P$ 0.001. DSI $=$ disease severity index.

${ }^{\mathrm{b}}$ CC45 = canopy closure at 45 days after emergence (DAE), R6 developmental stage. CC79 = canopy closure at 79 DAE, R7 stage.

c NS: not significant at the $P=0.05$ level. 
low temperature, and can be prevented by even slight drying of soil $(11,25,30,31)$. Higher air temperature and direct light penetration under a less dense canopy can also reduce survival and germination of ascospores on the leaf surface $(2,6)$. Wider within-row plant spacing can reduce disease spread by plant to plant contact $(5,10,32)$. It is also possible that the high plant mortality rates verified when 12 to 16 plants/m were tested had increased white mold intensity by inducing sclerotia to germinate myceliogenically, as demonstrated by $\mathrm{Tu}$ (32).

The predominance of dry and sunny days during the fall-winter in central and southeastern Brazil could be a favorable factor for the reduction of disease with decreasing within-row plant densities. In Canada, where reduction of within-row densities had no effect on white mold occurrence, environmental conditions are different from those in Brazil, and furthermore, the larger space between plants in the row tested by Saindon et al. (23) was 0.10 to $0.13 \mathrm{~m}$, i.e., 7.7 to 10 plants $/ \mathrm{m}$, densities greater than 4 or 5 plants $/ \mathrm{m}$ used in the present study.

In soybean, similar yield across plant populations resulted from equilibration of crop growth rate by the early reproductive period, which results in an equivalent number of pods $/ \mathrm{m}^{2}(3,4)$. We observed an equivalent number of pods $/ \mathrm{m}^{2}$ across plant densities in the 2000 experiment when the final plant population varied from 104,600 to 284,000 plants/ha. In the 2001 experiment, when weather was less favorable for white mold, the number of pods $/ \mathrm{m}^{2}$ diminished with reduction of within-row plant densities. However, in both experiments, the number of seeds per pod and seed weight increased as plant population decreased, compensating for the number of pods $/ \mathrm{m}^{2}$. Consequently, yields increased as plant densities decreased.

Results of this study were obtained with overhead sprinkler irrigation that supplied $5.0 \mathrm{~cm}$ of water per week after seedling emergence, as usually used in the region. However, most common bean fields cultivated during the fall-winter season in Brazil are irrigated by center pivots. With this system, water is generally applied more frequently than with overhead sprinkler irrigation. Thus, common bean developing under center pivot may be more prone to white mold, and the benefits of using wider within-row plant spacing might be higher than with an overhead sprinkler irrigation system.

A modification of within-row plant distributions was tried in 2000 when single and equidistant plants were compared to equidistant groups of three plants. Withinrow plant distributions affected neither disease intensity nor seed yield.

By reducing plant population to 90,000 plants/ha, the average lower within-row densities tested in this study, the amount of seed needed to plant any given area would be reduced by half compared to current practices. For sowing such low seed density, the use of modern precision planters may be necessary to assure a uniform plant population. Most foliar diseases of common bean are also less intense in low than in high plant populations $(24,34)$. Good weed control is important (29,33), and high-vigor seeds must be used in the field if seeding rates are lowered.

In summary, we found that equidistant spacing of 4 plants $/ \mathrm{m}$, compared with the current 10 to 12 plants $/ \mathrm{m}$, reduced white mold intensity and improved seed yield under medium or high disease pressure in southeastern Brazil, and its effect is additive to fungicide applications. Use of equidistant groups of three plants was not more effective than single and equidistant plants in white mold control.

\section{ACKNOWLEDGMENTS}

R. F. Vieira, T. J. Paula Júnior, and J. E. de S. Carneiro are supported by CNPq (Brasilia, Brazil). H. Teixeira is supported by FAPEMIG (Belo Horizonte, Brazil)

\section{LITERATURE CITED}

1. Bardin, S. D., and Huang, H. C. 2001. Research on biology and control of Sclerotinia diseases in Canada. Can. J. Plant Pathol. 23:88-98.

2. Caesar, A. J., and Pearson, R. C. 1983. Environmental-factors affecting survival of ascospores of Sclerotinia sclerotiorum. Phytopathology 73:1024-1030.

3. Carpenter, A. C., and Board, J. E. 1997. Branch yield components controlling soybean yield stability across plant population. Crop Sci. 37:885-891.

4. Carpenter, A. C., and Board, J. E. 1997. Growth dynamic factors controlling soybean yield stability across plant populations. Crop Sci. 37:1520-1526.

5. Chad, D. L., Renner, K. A., Penner, D., Hammerschmidt, R., and Kelly, J. D. 2005. Glyphosate-resistant soybean management system effect on Sclerotinia stem rot. Weed Technol. 19:580-588.

6. Clarkson, J. P., Staveley, J., Phelps, K., Young, C. S., and Whipps, J. M. 2003. Ascospore release and survival in Sclerotinia sclerotiorum. Mycol. Res. 107:213-222.

7. Ferreira, C. M., dos Santos, M. L., Braga, M. J., and Del Peloso, M. J. 2006. Aspectos Econômicos. Pages 19-40 in: Feijão. C. Vieira, T. J Paula Júnior, and A. Borém, eds. Editora UFV, Viçosa, MG.

8. Hall, R., and Phillips, L. G. 1996. Evaluation of parameters to assess resistance of white bean to white mold. Annu. Rep. Bean Improv. Coop. 39:306-307.

9. Hao, J. J., Subbarao, K. V., and Duniway, J. M. 2003. Germination of Sclerotinia minor and $S$. sclerotiorum under various soil moisture and temperature combinations. Phytopathology 93:443-450.

10. Hoes, J. A., and Huang, H. C. 1985. Effect of between-row and within-row spacings on development of Sclerotinia wilt and yield of sunflower. Can. J. Plant Pathol. 7:98-102.

11. Hunter, J. E., Pearson, R. C., Seem, R. C., Smith, C. A., and Palumbo, D. R. 1984. Relationship between soil moisture and occurrence of Sclerotinia sclerotiorum and white mold disease on snap beans. Prot. Ecol. 7:269-280.

12. Kane, M. V., and Grabau, L. J. 1992. Early planted, early maturing soybean cropping system: Growth, development and yield. Agron. J. 84:769-773.

13. Kolkman, J. M., and Kelly, J. D. 2002. Agronomic traits affecting resistance to white mold in common bean. Crop Sci. 42:693-699.

14. Mila, A. L., and Yang, X. B. 2008. Effects of fluctuating soil temperature and water potential on sclerotia germination and apothecial production of Sclerotinia sclerotiorum. Plant Dis. 92:78-82.

15. Napoleão, R., Café Filho, A. C., Lopes, C A., and Nasser, L. C. B. 2006. Effect of plant spacing and bean cultivar on white mold and seed sanity. Summa Phytopathol. 32:63-66.

16. Oliveira, S. H. F. de, Kimati, H., and Tofoli, J. G. 1999. Differential action of fungicides on life cycle of Sclerotinia sclerotiorum of bean Summa Phytopathol. 25:256-261.

17. Park, S. I. 1993. Response of bush and upright plant type selections to white mold and seed yield of common beans grown in various row widths in southern Ontario. Can. J. Plant Sci. 73:265-272.

18. Paula Júnior, T. J., Vieira, R. F., Teixeira, H., Coelho, R. R., Carneiro, J. E. de S., Andrade, M. J. B., and Rezende, A. M. 2008. Informações técnicas para o cultivo do feijoeirocomum na região central brasileira: 2007 2009. Epamig, Viçosa, MG.

19. Phillips, A. J. L. 1987. Carpogenic germination of sclerotia of Sclerotinia sclerotiorum: A review. Phytophylactica 19:279-283.

20. Ribeiro, N. D., Cargnelutti Filho, A., Jost, E. Poersch, N. L., and Trentin, M. 2004. Modification in phenological and morphological characters due to plants density in bean cultivars. Rev. Bras. Agroc. 10:167-173.

21. Ribeiro Júnior, J. I. 2001. Análises estatísticas no SAEG. Editora UFV, Viçosa, MG.

22. Saindon, G., Huang, H. C., and Kozub, G. C. 1995. White-mold avoidance and agronomic attributes of upright common beans grown at multiple planting densities in narrow rows. J. Am. Soc. Hortic. Sci. 120:843-847.

23. Saindon, G., Huang, H. C., Kozub, G. C., Mündel, H. H., and Kemp, G. A. 1993. Incidence of white mold and yield of upright bean grown in different planting patterns. J. Phytopathol. 137:118-124.

24. Schwartz, H. F. 1981. Interaction between plant density and bean disease severity in Colombia. Annu. Rep. Bean Improv. Coop. 24:62-63.

25. Schwartz, H. F., and Steadman, J. R. 1978. Factors affecting sclerotium populations of, and apothecium production by Sclerotinia sclerotiorum. Phytopathology 68:383-388.

26. Souza, A. B., Andrade, M. J. B., Muniz, J. A., and Reis, R. P. 2002. Plant populations and levels of fertilization and liming for the common bean crop (Phaseolus vulgaris L.) in a low fertility soil. Ciênc. Agrotec. 26:87-98.

27. Steadman, T. R., Coyne, D. P., and Cook, G. E. 1979. Reduction of severity of white mold disease on Great Northern beans by wider row spacing and determinate plant growth habit. Plant Dis. Rep. 57:1070-1071

28. Sun, P., and Yang, X. B. 2000. Light, temperature, and moisture effects on apothecium production of Sclerotinia sclerotiorum. Plant Dis. 84:1287-1293.

29. Teixeira, I. R., Andrade, M. J. B. de, Carvalho, J. G. de, Morais, A. R. de, and Corrêa, J. B. D. 2000. Response of bean (Phaseolus vulgaris $\mathrm{L}$. cv. Pérola) crop to different sowing densities and nitrogen levels. Ciênc. Agrotec. 24:399408.

30. Teo, B. K., and Morrall, R. A. A. 1985. Influence of matric potentials on carpogenic germination of sclerotia of Sclerotinia sclerotiorum. I. Development of an inclined box technique to observe apothecium production. Can. J. Plant Pathol. 7:359-364. 
31. Teo, B. K., and Morrall, R. A. A. 1985. Influence of matric potentials on carpogenic germination of sclerotia of Sclerotinia sclerotiorum. II. A comparison of results obtained with different techniques. Can. J. Plant Pathol. 7:365369.

32. Tu, J. C. 1987. Epidemiology of white mold (Sclerotinia sclerotiorum) in navy bean (Phaseolus vulgaris). Med. Fac. Landbouww. Rijksuniv. Gent 52:787-796.
33. Valério, C. R., Andrade, M. J. B. de, and Ferreira, D. F. 1999. Behavior of Aporé, Carioca and Pérola common bean cultivars in different plant populations and row spacing. Ciênc. Agrotec. 23:515-528.

34. Vieira, R. F., and Paula Júnior, T. J. 2006. Sementes: Veículos de disseminação de patógenos. Pages 437-476 in: Feijão. C. Vieira, T. J. Paula Júnior, and A. Borém, eds. Editora UFV, Viçosa, MG.
35. Vieira, R. F., Paula Júnior, T. J., Peres, A. P and Machado, J. C. 2001. Fungigation on white mold control of common bean and seed transmission of the pathogen. Fitopatol. Bras 26:770-773

36. Vieira, R. F., Pinto, C. M. F., and Paula Júnior, T. J. 2003. Chemigation with benomyl and fluazinam and their fungicidal effects in soil for white mold control on common beans. Fitopatol. Bras. 28:245-250. 